\title{
O SÍNODO DE MISSOURI E O SEMINÁRIO TEOLÓGICO-PEDAGÓGICO EM SÃO LOURENÇO DO SUL- RS (1903-1905)
}

\author{
Patrícia Weiduschadt ${ }^{1}-$ \\ Universidade Federal de Pelotas-UFPEL \\ prweidus@gmail.com. \\ Elomar Tambara ${ }^{2}-$ \\ Universidade Federal de Pelotas- UFPEL- \\ tambara@ufpel.edu.br
}

\section{RESUMO}

No início do século XX, o Sínodo de Missouri, igreja luterana confessional oriunda dos Estados Unidos (atual IELB) instala-se entre as comunidades pomeranas na região meridional do RS. O Sínodo de Missouri buscou implantar um projeto escolar e religioso diferenciado, com uma formação doutrinária luterana ortodoxa, construindo aspectos identitários através da religião e escolarização. O referencial teórico foi embasado em Bourdieu (2002, 1996a, 1989) nos conceitos de habitus, as disposições interiorizadas na formação dos primeiros estudantes, bem como o fortalecimento do campo religioso em relação ao campo escolar ou familiar. Na análise dos caminhos do Sínodo são apresentadas características que o distinguem: a necessidade de formar pastores e professores, qualificando-os no trabalho religioso e escolar. Assim, o surgimento do primeiro seminário no interior de São Lourenço do Sul entre os pomeranos propiciou um estudo do projeto do Sínodo na compreensão da identidade teológica pedagógica dos primeiros estudantes, que, posteriormente, atuaram nas comunidades pomeranas. Foi tratado a justificativa do seminário, o cotidiano, o currículo e o fechamento. Compreende-se a importância do seminário na necessidade de expansão do Sínodo e na preocupação com a educação.

Palavras-chave: Sínodo de Missouri; luteranismo; seminário; pomeranos.

\section{THE MISSOURI SYNOD AND THE THEOLOGICAL PEDAGOGICAL SEMINAR IN SÃO LOURENÇO DO SUL - RS (1903-1905)}

\section{ABSTRACT}

At the beginning of the 20th century, the Missouri Synod, a confessional Lutheran Church which originated in Missouri, United States (named IELB in Brazil), settles among Pomeranian communities in the Southern region of Rio Grande do Sul. The Missouri Synod intended to install a differentiated scholar and religious project, with an orthodox Lutheran doctrinaire constitution, forming identity aspects by means of religion and education. The theoretical reference of this work is based in Bourdieu (2002, 1996a, 1989), in the habitus concepts, the arrangements internalized in the education of the first students, as well as the fortification of the religious field in regard to educational or familiar fields. When analysing the paths of Missouri Synod, some characteristics which differentiate it are presented: the necessity to form Ministers and Teachers, qualifying them to work with religion and education. Thus, the appearance of the first seminar among Pomeranians in the countryside of São Lourenço do Sul propitiated a study of the project of Missouri Synod about the comprehension of the theological pedagogical identity of the first students who, later on, operated in the Pomeranian communities. There were discussed the justification of the seminar, its daily activities, curriculum and closure. The importance of the seminar is comprehended in the necessity of the expansion of Missouri Synod and its preoccupation with education.

Keywords: Missouri Synod; Lutheranism; seminar; Pomeranians. 
O presente trabalho faz parte de dissertação de mestrado e objetiva analisar o projeto educacional do Sínodo de Missouri ${ }^{3}$ na fundação do primeiro seminário no interior de São Lourenço do Sul, especificamente na localidade de Bom Jesus. Esta instituição instalou-se no Brasil em 1900 e, comunidades de imigração alemã, especificamente entre os pomeranos. Buscou-se compreender, neste contexto, a formação da identidade teológicapedagógica neste projeto educacional da referida instituição.

Como suporte metodológico utilizou-se dois periódicos, estes organizados pelo Sínodo: o Der Lutheraner, (editado nos Estados Unidos- (1898-1925) e o Kirchenblatt (editado no Brasil -1903-1925). Ainda foi analisado revistas do Sínodo que foram editadas posteriormente: o Mensageiro Luterano e O Jovem Luterano (décadas de 1940-1950), nos quais constavam relatos dos alunos e professor do primeiro seminário. O referencial teórico baseou-se nos conceitos de campo e de habitus defendidos por Pierre Bourdieu (2002; 1996a; 1996b; 1989) para entender a constituição, o cotidiano e os conflitos e disputas envolvidas neste projeto educacional até o término e as consequiências da formação do seminário para a consolidação das escolas paroquiais dirigidas pelo Sínodo de Missouri na região de Pelotas e São Lourenço do Sul.

\section{Contextualização do trabalho educacional do Sínodo de Missouri}

O Sínodo no trabalho de missão, através dos periódicos e dos seus documentos defendeu a posição de ser uma igreja baseada na verdadeira fé luterana. A organização das comunidades, de forma hierárquica, primou por este objetivo.

No primeiro número do Kirchenblatt , aparece a convicção de o Sínodo expandir-se através da missão e ser completamente confessional.

Com nosso trabalho e a ajuda de Deus, almejamos alcançar um alvo bem específico: estabelecer um Sínodo fiel à profissão luterana nesse país. Mesmo se a sua presença for modesta cumprirá a sua missão. Mesmo um pequeno grupo luterano pode, se for fiel, cumprir o seu papel de guardião, defensor e pregador do puro evangelho. A influência de um Sínodo fiel e corajoso, que leva a sério seu chamado, vai além de todas as fronteiras. (KIRCHENBLATT, 01/11/1903, Ano 1, nº 1, p. 2)

O objetivo parece ser claro, o Sínodo mantinha uma preocupação com a missão, em termos de qualidade, não somente em filiar fiéis. Estes fiéis precisavam ser educados e admoestados na fé e doutrina verdadeira. Esta educação, como se apontou, não era só conhecer a doutrina, mas, também, possuir modos de conduta desejáveis que coincidissem com os preceitos do Sínodo. Não importava para a instituição contar com um número pequeno de adeptos, era necessário que esses se adequassem à doutrina pregada pelo Sínodo. Esta característica acaba sendo diferente do Sínodo Riograndense ${ }^{4}$, que fortalecia sua instituição de outro modo, buscava as comunidades e se adaptava num primeiro momento a sua realidade, para depois conseguir a adesão dos fiéis. É possível perceber ainda na apresentação do Kirchenblatt a necessidade de divulgar a doutrina do Sínodo de Missouri de forma inovadora, para que os fiéis fossem educados e formados naqueles preceitos:

Existem, sim, muitos luteranos no Rio Grande do Sul, mas os pastores que deveriam reunir as congregações, não o fizeram até agora. Agiram de forma infiel, abandonado a sua profissão de fé.[...] Nós, todavia, não permitiremos ser desnorteados por esses fatos; sabemos de antemão que colocaremos nosso jornal à disposição de uma causa oprimida e humilhada. Isto nos dá ainda maior conviç̧ão de estar ao lado da causa 
luterana que está traída, abandonada e oprimida, dando-lhe todo nosso apoio. Queremos tornar o nome 'Luterano' novamente conhecido e utilizado. (KIRCHENBLATT, 01/11/1903, Ano 1, nº 1, p. 1)

O Sínodo faz questão de reforçar que as comunidades ditas evangélicas, não podiam considerar-se luteranas, porque não haviam sido preparadas para isto. Organizaram um periódico para divulgação de suas idéias e preceitos, sendo relevante a difusão da educação nas comunidades.

Entretanto, nem sempre era possível a adesão completa dos membros. O Sínodo Riograndense era criticado pelo Missouri na forma de atendimento, especialmente na despreocupação doutrinária. Entretanto, o Missouri apostava numa posição mais radical e hierárquica, por isso, precisava contar com pessoas preparadas para o trabalho missionário.

Daí a necessidade de pessoal qualificado para trabalhar nas comunidades e possibilitar a doutrinação dos fiéis de forma eficiente, tanto na igreja como nas escolas inseridas no Sínodo de Missouri.

Pode-se perceber que o estímulo em ter no Brasil um trabalho proveitoso dependia dos pastores e dos professores que iriam educar e doutrinar as comunidades. A educação para o Sínodo ocupava um lugar central, no sentido de orientar o grupo em que eles estavam inseridos. O relato pretendeu colocar o trabalho anterior dos pregadores como irresponsável e sem fundamentação doutrinária. As críticas recaíam no trabalho das igrejas luteranas instaladas até então, elas serviam apenas para reconciliar as comunidades e se adaptavam ao meio comunitário a fim de conseguir vantagens. A acusação sobre o trabalho dos pregadores era de eles não terem preparo algum, apenas usarem as vestes pastorais como um símbolo, não terem preparo teológico e nem pedagógico para orientar as comunidades. Também a conduta deles era criticada. Não possuíam uma postura moral adequada para o cargo de pastor. Assim, o relato de Broders ${ }^{5}$ no Der Lutheraner busca uma diferenciação e uma legitimação no trabalho missionário.

Se eu fosse um espírito errante e um pregador mentiroso eu pensaria somente em comer e beber, eram assim os exemplos dos pregadores para aquela gente. Se eu tivesse com estes transeuntes feito amizades, ali eles teriam tratado-me bem. Mas como eu não fiquei ao nível deles, eles me lançaram desafios. A nossa tarefa vai permanecer ao contrário daqueles matadores de almas de pessoas simples que com as almas enganadas acreditam que possam alcançar a graça de Deus. (DER LUTHERANER, 25/06/1901, Ano 57, no 13 , p. 197)

A conduta dos pastores que atuavam na época não era tolerada pelo Sínodo. Não se admitia fazer acordos com pessoas despreparadas. Há uma aposta na diferença do trabalho. É preciso ressaltar que a preparação das pessoas era necessária, para atingir objetivos de formação doutrinária e diferentes modos de conduta das comunidades. Era visível que o projeto do Sínodo de Missouri não iria adiante sem o investimento necessário em pastores e professores. Este discurso tinha que ser reconhecido entre os do Sínodo de Missouri nos Estados Unidos, a legitimação desta perspectiva era aceitável, entretanto, entre o grupo a ser conquistado era difícil o reconhecimento e a legitimação. Em estudos de Bourdieu (1996b, p. 112), o autor coloca que a distinção dos grupos precisa ser institucionalizada sendo visível e manifesta, então:

[...] torna-se visível, manifesto, tanto para outros grupos como para si mesmo, atestando a sua existência enquanto grupo conhecido e reconhecido, e afirmando sua pretensão à institucionalização. $\mathrm{O}$ mundo social é também representação e vontade; existir socialmente é também ser percebido, aliás, percebido como distinto. (BOURDIEU, 1996b, p. 112) 
O que se pretende analisar são as formas como o Sínodo justificou a sua instalação. Destacou-se como um grupo diferenciado dos demais que aqui se encontravam. No trabalho, não cabe inferir se realmente ele era, mas sim avaliar o que representou a tentativa de se colocar como distinto, e aí residiu um apelo moral forte na conduta das comunidades, primeiramente representada pelo pastor e professor e, logo em seguida, na educação através das escolas e igrejas. Era necessária a percepção de ser distinto e uma das formas de provar esta distinção era promover uma institucionalização agregada com a formação e organização das comunidades.

Nos primeiros anos o Sínodo perseguiu estes objetivos relatando nos periódicos o crescimento das comunidades e ressentindo a falta de pastores e professores no trabalho, atribuindo a falta de recursos humanos ao pouco crescimento do trabalho.

Dessa forma, a preocupação era grande em investir na formação de professores e pastores para a sustentação do trabalho do Sínodo. Prova disto foi o projeto da fundação do seminário nas primeiras comunidades que aceitaram o Sínodo.

\section{Seminário em Bom Jesus \\ Justificativa da fundação do Seminário}

A preocupação com a formação de pastores e professores era acentuada no Sínodo de Missouri. Nos primeiros relatos da instalação no Brasil era apontada a necessidade de difundir a doutrina através da preparação de pessoas para atuar nas escolas e igrejas no Brasil. Em virtude, de haver poucos pastores disponíveis a vir no Brasil realizar o trabalho de missão, o Sínodo percebeu que era mais vantajoso formar pessoal entre os brasileiros.

Como foi apontado, a preocupação sempre foi com a qualidade doutrinária das pessoas envolvidas nas comunidades. O Sínodo buscou diferenciar-se no conhecimento bíblico e na difusão de uma doutrina luterana pura, ou seja, alinhada com as proposições do Livro de Concórdia de Lutero. O projeto inicial nos Estados Unidos contemplou a formação de professores e pastores desde a fundação desta instituição. Como foi visto anteriormente, a preocupação do Sínodo de Missouri era fortalecer as bases doutrinárias a partir da fundação de igrejas e, junto com elas, escolas. Nessa perspectiva, havia uma necessidade clara de estabelecer uma diferenciação das demais organizações de cunho luterano no Brasil, como as igrejas independentes ${ }^{6}$ ou ligadas ao Sínodo Riograndense.

Essa diferenciação estaria centrada em sistematizar o conhecimento da doutrina luterana através de pastores e professores com formação acadêmica e teológica específica. Já era de praxe o Sínodo em solo norte americano adotar este sistema. Aqui no Brasil era necessário estabelecer um sistema semelhante para continuar a propagação da missão da igreja, atendendo aos seus interesses.

Os relatos da importância em fundar o seminário aparecem de forma clara. No Der Lutheraner foi mencionado de forma positiva a decisão de, em terras brasileiras, ser construída uma escola de formação.

Logo que foi fundado o Sínodo nos Estados Unidos em 1839 pelos nossos pais luteranos, já se tinha a preocupação dos fundadores em construir um instituto para a formação de pastores e professores. No número mais novo do Kirchenblatt é colocado a necessidade de um instituto para a formação de pastores e professores.[...] O motivo e o objetivo desta constatação é reunir pessoas jovens com dons para o estudo teológico junto com conhecimentos científicos e clássicos, que eles poderão ser os pastores e professores de sua própria terra.[...] (DER LUTHERANER, 19/01/1904, Ano $60, n^{\circ} 2$, p. 22)

O relato salienta a necessidade de uma instituição de formação de professores e pastores por já ser um costume do Sínodo nos Estados Unidos. É entendido que os jovens 
precisam se engajar no trabalho da igreja, em especial os jovens que moram no Brasil. $\mathrm{O}$ Sínodo enfatiza a necessidade de preparar alunos jovens para o trabalho religioso, mas também escolar, a fim de estabelecer uma formação diferenciada no trabalho da igreja. Assim, como no Der Lutheraner, periódico americano distribuído por todos os lugares em que o Sínodo mantinha missão, o Kirchenblatt, periódico brasileiro relata de forma semelhante as notícias da constituição do Seminário

Um Instituto para formação de pastores e professores. Este título designa algo que só é totalmente compreendido quando levado a cabo, mas temos a esperança de que ele trará torrentes de benção sobre nossa igreja nesse Estado. Objetivo e alvo deste empreendimento é capacitar jovens vocacionados, ensinando-os sobre ciência e tecnologia, de forma que possam servir de professores ou pastores em sua própria região. (KIRCHENBLATT, 01/12/1903, Ano 1, nº 3, p. 23)

Diante dessas afirmações percebe-se a necessidade da formação de jovens no Brasil, com isso o Sínodo pretendia demarcar uma identidade própria, querendo instaurar o habitus na formação destes jovens, e, consequentemente nas comunidades.

Um motivo determinante era o custo financeiro de formar pastores e professores no Brasil. Além disso, a maioria dos pastores não queria sair dos Estados Unidos, onde tinham uma situação mais estável, e, mesmo aqueles que vinham, acabavam tendo um custo elevado nas viagens longas e demoradas de navio e, ainda, havia a possibilidade de estes pastores imigrantes não se adaptarem à realidade brasileira. Como pode ser percebido nas reportagens dos dois periódicos.

Uma segunda constatação cai diante do nosso olhar: que este custo elevado da viagem poderia ser poupado. Este é o ponto principal, que a igreja local faça os seus nascidos aqui fortalecerem as igrejas, para que ela cresça em nosso meio. Então, primeiro se a santa igreja forma pastores e professores ela pode se tornar auto-suficiente e não ficar dependente do exterior. (DER LUTHERANER, 19/01/1904, Ano 60, nº 2, p. 22)

Da mesma forma o Kirchenblatt corrobora os motivos de fundar um seminário.

Dois fatores em especial nos estimularam a elaborar o presente projeto: o alto custo em se trazer trabalhadores de fora, e , segundo o mais importante, servir à igreja com servos nascidos e criados em seu meio, fazendo com que a igreja estimule seu próprio crescimento e fortalecimento. Pois, só depois da igreja formar seus pastores e professores é que ela pode esperar um dia ser totalmente auto-suficiente e independente do exterior. (KIRCHENBLATT, 01/12/1903, Ano 1, nº 3, p. 23)

Era necessário legitimar a formação dos pastores e professores em pessoas consideradas brasileiras. Era preciso provar e construir uma identidade nas comunidades com orientadores das próprias localidades, mas que tivessem a formação planejada pelo Sínodo. A autonomia apregoada pelo Sínodo referia-se especialmente ao lado financeiro. Em muitos momentos os relatos nos periódicos apontam no início do século as dificuldades financeiras do Brasil, com um processo inflacionário altíssimo e com a desvalorização da moeda, tornando difícil o auxílio do Sínodo e a permanência de pastores americanos em terras brasileiras. Entretanto, é considerável a motivação em oferecer formação a pessoas residentes no país, pois necessariamente contribuiriam para uma melhor identificação da 
igreja nesta realidade. A credibilidade e a legitimidade do Sínodo seria fortalecida com pastores e professores atuando em comunidades das quais eles faziam parte ainda jovens.

A primeira experiência de comunidades ligadas ao Sínodo deu-se nas regiões de Pelotas e São Lourenço do Sul. ${ }^{7} \mathrm{O}$ trabalho de expansão da organização era maior nesta região do Estado. Como a preocupação com o ensino da educação cristã e escolar era fundamental para o Sínodo, foram enviados alguns pastores e professores dos Estados Unidos para consolidar o trabalho. ${ }^{8}$ Estes pastores tinham formação teológica em seminários específicos dos Estados Unidos e eram de descendência alemã.

Um dos primeiros pastores enviado ao Brasil foi John Hartmeister. Chegou em Bom Jesus, São Lourenço do Sul em 1901, fundando uma das primeiras comunidades do Sínodo de Missouri, e, junto com esta comunidade, começou a funcionar o primeiro seminário de formação teológica para pastores e professores.

Este pastor fundou e foi diretor do Instituto de Bom Jesus, com objetivo de formar pastores e professores. Em um artigo do jornal Kirchenblatt intitulado "Ein Institut zur Ausbildung von Leheren und Predigern" (Um Instituto para a formação de professores e pregadores) redigido por Hartmeister (1904,p.37) retrata o início do Seminário.

Na segunda semana após a Páscoa do ano passado estava reunida a Conferência Especial de São Lourenço na Comunidade de Bom Jesus.[...] Durante longo tempo e detalhadamente houve aconselhamento a respeito do assunto que está exposto no título deste artigo.

Estava claro a todos nós: caso a obra do Senhor carecesse de ser trabalhada devidamente, sim, que no futuro fosse ainda melhor apresentada de que agora era possível, então deveriam ser elaborados passos no sentido de se conseguirem trabalhadores capacitados. A classe de professores e pregadores em muitos lugares de nosso país é representada por pessoas que são totalmente incapazes para este mister. [...] Em resposta à proposta do pastor Mahler a conferência resolveu unanimente, de iniciar-se com a formação de jovens daqui para o trabalho da Igreja.[...] (HARTMEISTER, 1904, p. 37)

A capacitação de pessoas para o trabalho teológico e pedagógico era uma das justificativas para o Sínodo investir na formação de pessoal, a fim de difundir as doutrinas luteranas e propagar a sua missão, sem deixar de levar em consideração que seria menos dispendioso formar professores e pastores no Brasil do que financiar pessoas vindas de fora para o trabalho. Tinham consciência de que era preciso fortalecer a educação e a igreja dentro das comunidades já existentes.

Os primeiros passos precisavam ser dados para realização do projeto. A escolha do local foi em função da proximidade de Bom Jesus com comunidades ligadas ao Sínodo.

Pergunta-se hoje, muitas vezes, o porquê da opção em localizar o Instituto em Bom Jesus II, uma colônia no interior de São Lourenço. Porque não na própria sede municipal de São Lourenço? Ou mesmo na capital do Estado, Porto Alegre? Primeiramente, porque na sede municipal ainda não havia uma congregação do Sínodo de Missouri. Por outro, na capital do Estado, para onde mais tarde foi realmente transferido o Instituto, na época, faltava a devida infra-estrutura para absorver tal projeto. Optou-se por Bom Jesus II por várias razões. A congregação tinha uma grande propriedade. Nesta propriedade os futuros alunos poderiam plantar e, assim ajudar na sua 'pensão'. Havia também um galpão que, com algumas adaptações, podia servir como 'internato', e a escola local como sala de aula. Por outro, Bom Jesus, mesmo localizado no interior, favorecia como local, pois se achava rodeado de outras congregações do Sínodo de Missouri, o que facilitava o 
envio de gêneros alimentícios e, principalmente, alunos. (STEYER, 1999, p. 82)

A justificativa em começar o seminário de formação de pastores e professores era construir um estabelecimento cercado pelas comunidades pomeranas para reforçar o projeto do Sínodo em fortalecer os seus princípios através da educação, tanto cristã como geral. Bom Jesus ficava rodeado por comunidades recentemente ligadas ao Sínodo, todas elas ainda a serem conquistadas pela perspectiva de uma igreja confessional. A inculcação de novos preceitos de sistematização de religiosidade e ensino era preciso ser reforçada, então nada melhor que instalar um seminário para servir de modelo e parâmetro aos membros da comunidade.

A maior parte desses membros eram de origem pomerana. Mais de uma vez os pioneiros do Sínodo afirmaram que os pomeranos eram aparentemente passivos, mas precisavam ser conquistados. Eram também muito desconfiados, precisavam absorver a sua confiança. $^{9}$

Ao mesmo tempo, as comunidades que cercavam Bom Jesus poderiam colaborar e auxiliar este projeto. É visível a necessidade de colaboração, porque o Sínodo investiu na construção de um seminário no interior, um lugar afastado dos centros maiores, mas próximo dos seus fiéis.

De fato, era uma boa maneira de mostrar às comunidades o sistema de ensino que o Sínodo de Missouri pretendia realizar. A formação seria vista e acessível aos jovens que viviam no Brasil, em especial, àqueles de origem pomerana.

Como segundo nosso conhecimento ainda não existe tal estabelecimento, ao qual jovens dispostos a receberem formação para o trabalho poderiam dirigir-se. A conferência decidiu conseguir-lhes tal oportunidade aqui. Nas terras pertencentes a esta comunidade os estudantes poderiam, por meio do trabalho de suas próprias mãos contribuir (cooperar) para sua manutenção (sustento) (HARTMEISTER, 1904, p. 37. Tradução de Mores na Pasta 2483).

Sabiam que a maioria dos jovens ligados ao Sínodo de Missouri moravam na zona rural, por isso não seria tão difícil adaptarem-se às condições de estudantes e agricultores. $\mathrm{O}$ seminário estaria aberto aos jovens que se dispusessem a estudar e trabalhar na lavoura para conseguir o sustento. Eles, na maioria, já viviam da agricultura e poderiam assim conciliar o trabalho agrícola e os estudos. A maioria destes jovens possuía um habitus imbuído de religiosidade ligado com o trabalho. A partir da conceituação do habitus, percebe-se que a formação deste se dá através da inculcação de práticas que os indivíduos acabam aceitando como naturais e legítimas, mesmo diante das diferenças. Bourdieu, (1996b) analisa este conceito ao revelar que:

A estratégia universalmente adotada para eximir-se duradouramente da tentação de sair da linha consiste em naturalizar a diferença e transformá-la numa segunda natureza através da inculcação e da incorporação sob a forma de habitus. [...] O trabalho de inculcação através do que se realiza a imposição duradoura do limite arbitrário visa naturalizar as rupturas decisórias constitutivas de um arbitrário cultural [...] sob a forma dos sentidos dos limites, fazendo com que alguns mantenham a sua posição ou se conservem a distância enquanto outros se mantém em seu lugar e se contentam com o que são, a serem o que têm de ser, privando-os assim da própria privação. ( BOURDIEU, 1996b, p.102 e 103) 
Quando o autor se refere a "sair da linha", ele quer reforçar que os indivíduos não possuem tanta autonomia de escolha como parece. Na maioria das vezes, a incorporação do habitus se dá a partir de disposições que acabam se naturalizando e se legitimando para se adaptar às condições impostas.

Os estudantes possuíam estratégias e disposições interiorizadas de um habitus religioso e ascético que lhes permitiam conciliar a condição de estudantes para serem pastores ou professores, aí se legitimarem por possuírem certa diferenciação, com a condição de trabalharem na agricultura, porque também na perspectiva religiosa o trabalho possibilitava uma aproximação dos valores protestantes, em que o trabalho dignifica e aproxima de Deus.

\section{Os estudantes}

De acordo com o projeto inicial que se fundamentava em instalações simples e com poucos recursos, muitas vezes de forma improvisada, mas não desorganizada, os estudantes também foram buscados nas primeiras comunidades que o Sínodo conseguiu formar.

Segundo as Crônicas da Igreja, compêndio que conta a história da igreja do Sínodo de Missouri, o professor Hartmeister descreve a trajetória dos primeiros alunos:

[...]Cinco alunos se matricularam. Nenhum deles pertencia à minha congregação, mas um aluno era de uma localidade próxima de Bom Jesus. Chamava-se Emílio Wille, o qual durante muitos anos serviu a igreja como professor e pastor. [...] Um outro aluno veio da paróquia do Pastor A. Vogel (Santa Coleta). Foi ele Francisco Hoffmann, que depois serviu como professor de nossa igreja em diversas congregações.[...] Dois alunos vieram da Congregação de São Pedro. Um deles foi Evaldo Hirschmann, que serviu pastor em diversas paróquias.[...] $\mathrm{O}$ outro chamava-se $\mathrm{H}$. Drews. Este depois do fechamento do instituto em 1905, serviu como professor durante alguns anos, desistindo posteriormente. $\mathrm{O}$ quinto $\mathrm{e}$ último, o qual se matriculou mais tarde, fora enviado pelo pastor $\mathrm{H}$. Wittrock de Cruz Alta. Tratava-se do inteligente Adolfo Flor, que veio a falecer prematuramente a 10 de novembro de 1918. Foi esta a primeira e única classe do Instituto de Bom Jesus. (WARTH, 1979, p. 161)

De acordo com esta descrição, percebe-se que os primeiros cinco alunos eram na sua maioria das comunidades vizinhas, já ligadas ao Sínodo, ou fundadas por ele, como é o caso da São Pedro, sendo apenas um deles proveniente da região de Santa Cruz. Esta sucinta nota mostra que os integrantes deste primeiro projeto pretendiam receber uma formação teológica e também pedagógica.

Estes estudantes vieram de regiões próximas de Bom Jesus e foram convidados a partir da propaganda feita pelos pastores dos Estados Unidos.

Quando os primeiros pastores americanos propuseram a instalação do Instituto era preciso o aval da comunidade e o apoio dela para este projeto. Um dos primeiros alunos, Emílio Wille, foi contagiado por esta propaganda nos primórdios do lançamento desta idéia, como é contado num relato posterior em uma revista da Igreja:

Donde vieram os alunos para o novo Instituto? No sermão de propaganda para a obra no Domingo Misericordias Domini, o pastor W. Mahler dirigiu-se a um menino sentado perto do púlpito e disse: 'Aqui temos um moço apto para o estudo no novo Instituto'. O moço ficou tão impressionado que pediu licença aos pais para entrar no Instituto. Como velho pastor hoje ainda se lembra daquele dia e daquele momento. No decorrer do ano foram matriculados ao todo cinco alunos. (JOVEM LUTERANO, agosto de 1949, Ano X, nº 8, p. 119) 
Esse jovem que estava ouvindo o sermão era o pastor Emílio Wille, que também relata a sua emoção em outro periódico da igreja. Nesse relato Emílio Wille observa que a comunidade não acreditava ser importante formar pastores e fazer parte de uma igreja doutrinária, mas o jovem preocupava-se com o projeto:

Finalmente, depois de muitos prós e contras, foi resolvido conceder a instalação do Instituto. Entretanto, ainda foi feita a pergunta: 'Donde serão tirados os estudantes?' O pastor Mahler respondeu que se houvesse um colégio também seriam encontrados alunos. O signatário destas linhas via e ouvia o pastor Mahler pela primeira vez. As suas palavras tocaram-lhe o coração. Não esquecerei que enquanto falava se dirigia a mim, dizendo: 'Este jovem que aqui está já servirá para o nosso instituto'. Fiquei entusiasmado com aquelas palavras. Ao chegar em casa declarei aos meus pais que pretendia entrar naquele estabelecimento. No dia seguinte o pastor Hartmeister falou-lhes neste respeito. Finalmente consentiram nisto, ficando combinado que em breve fosse para a casa do pastor a fim de ajudá-lo na arrumação do instituto. [...] (EMÍLIO WILLE In: Mensageiro Luterano, abril de 1949, Ano XXXII, no 4, p. 26)

Nota-se os conflitos formados para constituir em realidade o projeto do Seminário. A aprovação dessa obra precisava ser dada pela comunidade local, em Bom Jesus e sustentada pelas comunidades vizinhas.

O estímulo em formar estudantes brasileiros tinha os motivos já apontados. É interessante notar que, mesmo a primeira Assembléia Sinodal do Missouri em 1904 tendo sido realizada em Rincão de São Pedro, região noroeste do Estado, o Instituto estava fortalecido na região meridional do Estado, contando com a adesão de quatro alunos e mais tarde um quinto aluno. (DER LUTHERANER, 1904)

$\mathrm{Na}$ ata da primeira reunião sinodal ficou relatada a preocupação com um estudo sobre a implantação e funcionamento do Instituto. (Ata da $1^{\circ}$ reunião do distrito-1904)

\section{Início do seminário- Descrição e constituição}

O seminário em Bom Jesus foi fundado em 27 de outubro de 1903, com apenas três alunos, matriculando-se logo em seguida mais dois alunos. Apesar de o seminário ter funcionado num curto período de tempo, ou seja, até 1905, acredita-se ser de extrema relevância a sua localização pela tentativa pioneira da igreja do Sínodo de Missouri estabelecer-se no Rio Grande do Sul e por ter influenciado significativamente a educação dos fiéis e das escolas que, posteriormente, permaneceram nas localidades próximas à região.

A documentação dessa época aparece em jornais ligados ao Sínodo, reforçando e apoiando esse projeto, com descrições e relatos do pastor Hartmeister. Era preciso encorajar as comunidades a apoiarem esta instituição. Em outro artigo do Kirchenblatt, o pastor Hartmeister com o título de "Ein Tag bei unsern Zoeglingen" (Um dia entre os nossos alunos) faz a descrição detalhada do local, tanto da localidade como das dependências do Instituto. Do mesmo modo é descrito o cotidiano destes alunos, desde o seu trabalho na agricultura, até o currículo aprendido na formação teológico pedagógica. O artigo é relatado como se o leitor estivesse viajando com o autor dentro da localidade, no seminário e nas aulas.

No início do artigo o autor começa relatando:

Desejo convidar o prezado leitor para fazer uma visita ao nosso 'Instituto'. Se o mesmo vem de longe, de uma viagem longa e penosa para a Colônia de São Lourenço não lhe deve causar contrariedade. [...] Primeiramente o 
caminho de Pelotas segue por campo chato, plano; mas aos poucos notamse elevações do solo e que dão a entender, que estamos chegando mais perto da região das matas e morros das colônias propriamente dita. [...] Finalmente entramos na picada de Bom Jesus, a qual também é chamada de 'Picada dos Pommer' ou velha estrada, e logo mais estamos no local do destino. A picada de Bom Jesus é uma das mais velhas picadas desta colônia e é quase toda habitada por pomeranos.[...] (HARTMEISTER, 1904, p. 180)

O relato começa com a parte geográfica, deixando bem claro que a localização é na zona rural, distante do centro do Estado e das cidades próximas. O autor reforça esta questão para explicar aos leitores a dificuldade encontrada de deslocamento e acesso ao local, valorizando esse empreendimento no interior. No final, deixa explicitado a colônia possuir uma predominância pomerana. Salienta-se, assim, a questão de etnia relacionada com o projeto de missão.

Logo depois de dar uma descrição mais geral da localidade e da igreja, o pastor relata de forma detalhada as dependências do seminário.

A primeira porta leva-nos para o galpão que serve como despensa e semelhantes. Daqui passamos por uma outra porta para a sala de estar. O espaço existente para cinco pessoas não era por demais grande, por isso foi necessário economizar onde era possível. Duas camas são como camarotes de navios, afixados um por cima da outra. Uma mesa longa, um banco e nas paredes espaços para pendurarem-se chapéus e roupas de trabalho preenchem a peça (HARTMEISTER, 1904, p. 182. Tradução de Mores, pasta $\left.n^{\circ} 2483\right)$.

A descrição do local apresenta a maneira simples da organização daquele seminário, não descuidando da organização para acomodar os estudantes que ali conviveriam.

Pode-se perceber num relato de Paul Schelp (1925) "Unser Seminar" (Nosso Seminário) em que é descrito o local que os estudantes teriam ficado.

Naturalmente não era uma construção majestosa de nossa comunidade. A foto mostra que ela é humilde. Era apenas um paiol vazio, que foi transformado em dois quartos. Um foi rebocado e tinha uma janela de correr. Este era o quarto de estudo. O quarto maior guardava-se as enxadas, arado, grade, o que o colono precisa.[...] Todo o trabalho de madeira (carpintaria) foi feito pelo próprio pastor Hartmeister. A terra pertencia à congregação.[...] (SCHELP, PAUL IN BEER, OTTO 1925, p.8).

É interessante notar que, na descrição do local em que estes estudantes ficariam eram acentuados o local de estudo e as ferramentas de trabalho, bem como se enfatizava o trabalho e a habilidade do pastor Hartmeister na carpintaria. Percebe-se assim a relação do trabalho com o estudo que estes estudantes possuíam e fica claro que deveriam permanecer no trabalho posterior como pastores e professores. Não havia nenhuma resistência dos estudantes para o trabalho na agricultura porque, como já foi destacado, eles possuíam um habitus voltado para conciliar o trabalho com a formação doutrinária que iriam receber. $\mathrm{O}$ que se defende na pesquisa em relação à ética protestante é ser a disposição em aceitar qualquer tipo de trabalho agradável aos preceitos religiosos defendidos pelo protestantismo. 
Ainda, dentro deste espírito de conciliar trabalho e estudo, o pastor Hartmeister reforçava a necessidade de continuar a formação de professores e pastores para haver uma sistematização de uma educação voltada para a doutrina do Sínodo.

Se uma Igreja, cuidou suficientemente para que haja professores em bom número e competente, então ela terá crescimento seguro e estável. Com isto também a unidade de espírito é essencialmente fomentada. Se, porém, cuidou negligentemente ou mesmo descuidou totalmente desta importante parte da missão, então sua decadência (ruína) pode estar assegurada (HARTMEISTER, 1904, p. 39)

O reforço em viabilizar o projeto do seminário do Sínodo de Missouri é apoiado, mais uma vez, em sistematizar a religião e o ensino através da organização religiosa ligada com a escolar. Hartmeister reafirmava a posição sinodal em fornecer formação teológica concomitante com a pedagógica para formar o pastor e professor, no mesmo sentido de diferenciação em relação a outras denominações religiosas.

\section{Cotidiano no seminário}

O cotidiano dos alunos é relatado de forma interessante nas fontes pesquisadas: tanto a rotina de trabalho, do estudo, das refeições e do convívio entre eles. Como é colocado na reportagem de Hartmeister.

Caso o nosso estimado hóspede queira passar um dia inteiro com os nossos alunos (educandos), então deverá estar de pé de manhã bem cedinho. Já antes do primeiro raio solar levantam-se. Cada um dirige-se para o seu trabalho: tratar os animais, ordenhar as vacas (tirar leite), carregar água (buscar água), cortar lenha, varrer o pátio e assim por diante. Assim o sol nascente quase sempre nos encontra no café da manhã. Findas a refeição e a devoção matutina, trabalha-se na lavoura. Ainda, aqui como em outra parte, tem lugar e trabalho na escola paroquial. (HARTMEISTER, 1904, p. 182)

No cotidiano do seminário os alunos estavam engajados em diferentes atividades, o trabalho fazia parte da rotina dos alunos, e era compreensível esta relação, na medida em que eram provenientes de famílias de agricultores, portanto seu habitus era constituído desses princípios. Mas, sobretudo, a identidade teológica pedagógica do Sínodo era enfatizar a valorização do trabalho.

[...] A capacidade de concentração mental, tanto quanto o sentimento de obrigação absolutamente essencial para o próprio trabalho, estão aqui combinados com uma economia estrita que calcula a possibilidade de altos vencimentos, um autocontrole e uma frugalidade que enormemente aumentam a produção. Isso fornece uma base das mais favoráveis para a concepção do trabalho com um fim em si, como um valor que é condizente com o capitalismo; as oportunidades de superar o tradicionalismo são aqui muito grandes devido à educação religiosa. [...] (WEBER, 1992, p. 40)

Dentro dessa perspectiva weberiana o trabalho seria interligado com a religião. $\mathrm{O}$ campo do trabalho reforçava no cotidiano protestante a legitimidade em conseguir alcançar a proximidade com a religião através de atividades ordenadas e regradas dos ofícios. A naturalidade colocada na relação de estudo, trabalho e religião era evidente na citação acima de Hartmeister. O autor situava o leitor do artigo no cotidiano dos alunos: a valorização do 
acordar cedo, do trabalho digno, das orações, ou seja, do regramento das atividades destes alunos.

Parece que, ao relatar o cotidiano dos alunos, era preciso, num certo sentido, justificar a eficiência da formação não só de professores e pastores, mas também de uma certa maneira igualar o cotidiano dos estudantes aos demais membros ou futuros membros da organização do Sínodo de Missouri, embora criando a diferenciação na escolarização e na religiosidade.

Ficou evidente que o campo religioso, levando em consideração a constituição do campo como uma relação de forças e de domínio, ficaria fortalecido na distinção, mobilizaria os demais, mas ele se fortaleceria no engendramento com os outros campos.

Com isso se quere dizer que a constituição dos campos está imbuída de conflitos e lutas, e o que determina as suas posições nesta estrutura são os habitus e a diferenciação que conseguem fazer dentro do espaço social. Na constituição de uma formação teológica pedagógica do Sínodo de Missouri o campo religioso parece reger o campo escolar e até o campo do trabalho, embora estes últimos possuam autonomia e especificidade própria. $\mathrm{O}$ engendramento dos diferentes campos dá-se no conflito e na tentativa de sobreposição ou subjugação de um campo pelo outro.

Em relação ao cotidiano dos alunos, o documento ainda relata que eles trabalhavam na horta após o café da manhã enquanto o pastor atendia à escola paroquial ou auxiliavam o pastor na escola. (HARTMEISTER, 1904).

Havia muitas dificuldades financeiras no cotidiano desses alunos. Além do trabalho e da sobrecarga de estudo, muitas vezes as refeições eram simples, pois o pastor Hartmeister sustentava-os na maior parte de suas necessidades com o ordenado de pastor. Como tão bem relata Emílio Wille, um dos primeiros alunos.

As refeições as tomávamos em companhia da família do professor, reverendo Hartmeister. A espôsa do professor foi uma verdadeira mãe para os estudantes. Levando em conta que os estudantes não pagavam pensão e que o professor não recebia ordenado além de o de pastor, bem se pode imaginar que não nos podia oferecer banquetes. Muitas vezes nossa 'mãe' não sabia o que por na mesa para saciar os estudantes famintos. Comia-se o que tinha: batata doce assada ou um pedacinho de pão de milho, etc. Nunca podíamos dizer que a família do nosso querido professor se servisse de uma refeição especial. Tudo quanto havia era fraternalmente dividido. [...] (EMÍlLIO WILLE In: Mensageiro Luterano, Abril de 1949, Ano XXXII, no 4 , p. 27)

Os estudantes viviam num ambiente familiar com o seu professor. Era simples a rotina diária e passavam por muitas dificuldades. Fica suposto que o Sínodo não estava investindo muito neste projeto. Ele deveria contar com a disponibilidade do pastor Hartmeister em acumular muitas tarefas e da boa vontade dos estudantes em suportar sacrifícios. As condições em que ficavam também não era uma das melhores. Conforme foi dito eles ficavam alojados em um galpão improvisado com aposentos para dormir e estudar, eram precárias as condições relatadas pelo pastor Hartmeister:

A porta que dava acesso ao quarto achava-se no interior do celeiro. Junto à janela havia uma mesa comprida para os rapazes trabalhar e estudar. Um banco fazia as vezes de cadeiras. [...] O quarto não era rebocado nem provido de aquecimento algum. Dias houve na estação mais fria em que não era possível aos rapazes trabalhar e estudar aí. Vinham então à nossa cozinha, onde tomavam conosco sempre as suas refeições. 
(HARTMEISTER, IN: Mensageiro Luterano, janeiro de 1951, Ano XXXVI, $\left.n^{\circ} 1, p .4\right)$

Nesse sentido, o cotidiano em conciliar trabalho e estudo apresentava muitas dificuldades, mas era valorizado e aceito este sacrifício para a capacitação de mais pessoas para o trabalho pedagógico e teológico.

\section{Currículo do Seminário}

Nas reportagens dos periódicos também é mencionada a estruturação do curso. Óbvio que o curso de formação de pastores e professores estaria estruturado de forma bem mais simples que nos Estados Unidos, tendo em vista as condições precárias das instalações e a falta de recursos humanos, tendo apenas um professor para o curso, que atendia simultaneamente a escola e a igreja. Mas é interessante notar a preocupação do Sínodo em divulgar o que se vinha fazendo e os conteúdos que os cursos abrangeriam.

[...] Devido à situação aqui da região, especialmente das colônias, serão iniciados dois tipos de cursos; em um, os alunos serão formados em quatro anos, estando aptos a serem professores. Eles poderão assumir um posto em algum lugar onde um pastor já lidera uma igreja.[...] (KIRCHENBLATT, 01/12/1903, Ano 1, nº 3, p. 23).

Havia preocupação com as escolas, porque os professores formados poderiam auxiliar os pastores que estavam sobrecarregados nas atividades da igreja e escola. Nesse sentido, para este primeiro curso era possível um término mais rápido para suprir uma necessidade local que acontecia. Então, no desenrolar do relato são apresentados os conteúdos essenciais de cada curso.

[...] aprenderão assuntos úteis no ensino escolar, como conhecimentos sobre a língua alemã e portuguesa; introdução à matemática; história, geografia e outros estudos relacionados. O outro curso de formação de pastores será mais longo devido a sua natureza, ministrando com isso maior volume de aulas. Em ambos os cursos, será dada ênfase a formação do espírito e caráter, visto que ela é mais necessária e útil que a formação da mente.[...]. (KIRCHENBLATT, 01/12/1903, Ano 1, no 3, p. 23).

De forma resumida, os conhecimentos eram de acordo com a realidade. Não eram privilegiadas as línguas clássicas como o grego, latim e hebraico, como aconteciam nos seminários dos Estados Unidos. ${ }^{10}$ Entretanto, desde o início, foi dada a ênfase na formação do caráter e do espírito dos jovens. Essa valorização dava-se em virtude de uma necessidade em formar e instaurar um habitus voltado para os princípios morais e religiosos da instituição.

Esse habitus não dependeria somente da doutrina apreendida e dos conhecimentos clássicos e religiosos assimilados, mas especialmente dos modos de conduta que a religiosidade forma. Uma evidência é a afirmação de o currículo do seminário dever privilegiar a formação do espírito. Concorda-se com WEBER (1982) ao analisar os estudos sobre religião.

[...] não é a doutrina ética de um religião, mas a forma de conduta ética a que são atribuídas recompensas que importa. Essas recompensas funcionam na forma e na condição dos respectivos bens de salvação. E essa conduta constitui o ethos específico de cada pessoa, no sentido sociológico.[...] (WEBER, 1982, p. 366, grifos do autor). 
A partir dos estudos de Weber, pode-se inferir que a doutrina por si só, ensinada tanto na formação dos pastores e professores, como nas escolas comunitárias mantidas pelo Sínodo, ou ainda, na igreja, não seria garantia para as pessoas participarem de acordo com os preceitos doutrinários. O que poderia garantir uma eficiente formação comunitária religiosa, especialmente no Sínodo de Missouri, seriam as condutas que as pessoas precisam adquirir para se sentirem pertencendo a uma religião e sendo aceitas na instituição. Nesse caso, os alunos do seminário não seriam formados somente para o conhecimento doutrinário, defendido pelo Missouri, precisavam ser educados em condutas que os levassem à prática desta doutrina.

Nos relatos posteriores do estudante Emílio Wille é possível perceber os conteúdos ali ministrados, confirmando o projeto inicial do Sínodo.

O horário regulamentar dos estudantes foi o seguinte: alvorada às 5 horas da manhã, com uma hora de tempo para se lavarem, além de outras ocupações, como tratar do animais, etc. Às 6 horas era servido café, seguido da devoção matutina. Uma hora das 6,30 ás 7,30 era consagrada ao estudo. Das 7,30 às 11,30 os rapazes se ocupavam na lavoura, porquanto deviam trabalhar quatro horas por dia para o seu sustento próprio. Das 11,30 às 12 era tempo livre. As $12 \mathrm{em}$ ponto era servido o almoço. Das 13,30 às 14 horas era o tempo de estudo. Das 14 às 17 horas havia aulas. Eram as seguintes matérias lecionadas: religião (Catecismo, História Bíblica e hinos), línguas (alemão, português e latim), História do Brasil e geral, geografia, história natural, aritmética, desenho, canto, caligrafia, além de outras matérias. (EMÍLIO WILLE In: Mensageiro Luterano, abril de 1949, Ano XXXII, nº 4, p. 27).

Esse relato é contado num período posterior, na visão de um dos primeiros alunos do Seminário. É destacada a rotina diária dos estudantes, confirmada por outras fontes, podendo perceber a valorização do trabalho no sustento dos seus estudos.

Hartmeister em 1904, em artigo publicado no Kirchenblatt, também reforça a organização curricular do Seminário.

A décima segunda hora reúne-nos novamente por ocasião do almoço. Então há hora de estudo por algum tempo e há o preparo para a freqüência às aulas, que normalmente têm seu início às 14:30 minutos. Elas (as aulas) são dadas na igreja (ou na escola). As segundas, quartas e sextas-feiras iniciaram com uma aula de Religião. O pequeno Catecismo, hinos e salmos são decorados e repetidos várias vezes, nosso Catecismo Sinodal (de Schwan) é explicado e todos os versículos decorados. Esperamos terminá-lo este ano. O ensino da Aritmética é dado por explicação oral das regras e por demonstração no quadro-negro. Exemplos e regras são anotados (lançados) em um caderno. São fixadas três horas semanais para este estudo. $\mathrm{O}$ mesmo número de aulas usamos para o ensino do alemão. Como manual de ensino usamos o $3^{\circ}$ livro de leitura da nova série de Concordia Publishing House. Regras e exemplos são tirados do trecho da leitura. (HARTMEISTER, 1904, p. 183)

Nesse relato, o currículo escolar da preparação dos jovens como pastores e também professores fica explicitado. Ficava claro o currículo desenvolvido de forma detalhada, até nos horários previstos para cada disciplina. Enfatizavam o ensino religioso e doutrinário do luteranismo, relacionado com os estudos clássicos do conhecimento, porque reconheciam que a formação cultural e geral destes estudantes era necessária e possibilitava uma distinção em relação a pastores sem formação de outra denominação religiosa. 
A preocupação com o ensinamento do Catecismo era essencial para a propagação das bases doutrinárias. A partir do ensinamento de Lutero, eles iriam conhecer a doutrina e a relação com a Bíblia, e assim poderiam exercer o papel de professores e pastores nas comunidades em que atuariam, com a devida distinção que o Sínodo pretendia propagar.

O relato faz questão de explicitar os horários das disciplinas, para dar um entendimento da sistematização do currículo e demonstrar a organicidade curricular. A identidade teológica pedagógica do Sínodo era construída e permeada por uma preocupação em sistematizar os conteúdos e oferecer, a partir da literatura de circulação da igreja, uma justificativa para a continuidade do projeto em formar professores e pastores no Brasil.

Neste mesmo relato, fazemos uma avaliação do primeiro ano de estudo dos jovens no Seminário.

O alvo principal sem dúvida foi alcançado. Todo o catecismo foi esclarecido e todos os versículos e perguntas e respostas de Schwan foram decorados. Além desses 15 hinos e 6 salmos, o catecismo menor de Lutero foi repetido inúmeras vezes, no alemão foi feito muita repetição no sentido das palavras e também na análise sintática, 11 trabalhos escritos foram terminados. Na matemática especialmente as 5 operações foram repetidas e as decimais e as fracionais concretizadas, a zoologia estava presente na instrução natural. Foi feito um passeio pela história universal e numa introdução do livrinho Kappes. As declinações e conjugações junto com formas irregulares foram repassadas em latim. As demais matérias foram distribuídas sem um livro especial de instrução o que dificultava o avanço do conhecimento. [...] (SCHELP, PAUL IN BEER, OTTO 1925, p.89).

$\mathrm{Na}$ avaliação do ano coloca-se o que tinha sido alcançado no aprendizado teológico e geral pelos estudantes. O currículo era apreendido nas formas de um ensino clássico. Era importante, junto com os ensinamentos doutrinários, sob a forma de conhecer o Catecismo, trabalhar com os alunos o conhecimento geral e clássico.

Podemos nós ver conforme a revista da igreja (Kirchenblatt) para que fim e para que alvo este estabelecimento surgiu. Assim registra: 'especialmente na colônia foi estabelecido dois tipos de cursos; um para jovens que durava quatro anos (tipo ginásio) estes podiam ser administrados pelos pastores do local, era dada a gramática da língua alemã e alguns conhecimentos de matemática, história e artística. E o segundo curso se dedicava mais para os pregadores aprofundando doutrinas e formação de caractéres teológicos este mais importante do que as formações científicas'. (SCHELP, PAUL IN BEER, OTTO 1925, p.86).

Ficava evidenciada a necessidade de organizar o currículo de forma a atender a formação geral e a formação teológica. O primeiro nível seria de conhecimento geral para dar uma fundamentação clássica para os jovens, a fim de que eles pudessem ter um embasamento para no futuro se tornarem pastores, ou seja, consolidava-se um conhecimento geral para, na próxima etapa, aprofundar as doutrinas e os fundamentos teológicos de que os pastores se utilizariam no exercício de suas funções.

Mesmo assim, aparecem nos relatos as dificuldades na consolidação do cumprimento do conteúdo programático como falta de material didático: mapas no trabalho da geografia, livros no conhecimento das línguas, além de tempo reduzido de que os estudantes dispunham para um melhor aproveitamento. (HARTMEISTER, 1904)

$\mathrm{Na}$ verdade, o relato quer mostrar o esforço deste projeto. Mesmo o Instituto sendo precário nas instalações, em recursos humanos e na falta de material didático, era realizado um trabalho eficiente e de formação. 
No final do artigo, Hartmeister reclama das dificuldades encontradas em manter o Instituto e da falta de tempo dos estudantes em se dedicar aos estudos de forma integral. Ressalta que "todas as horas do dia são preenchidas com trabalho honesto e penoso" (HARTMEISTER, 1904, p.184), destacando a necessidade em justificar que os alunos não estavam ociosos. Eles sabiam da realidade que os agricultores viviam, porque eles trabalhavam da mesma maneira. O trabalho ficava valorizado, já que na cultura em que estavam inseridos os membros do Sínodo de Missouri havia uma ética voltada para o trabalho. O relato enfatiza a importância do trabalho, mas, em contrapartida, chama atenção para a necessidade de uma dedicação maior dos estudantes no conhecimento da doutrina e nos ensinamentos clássicos, até como uma forma de distinção e diferenciação.

Por isso, no final do artigo de Hartmeister é feito um apelo ao Sínodo para que se mantenha a formação de professores e pastores.

[...] Se no futuro a Igreja evangélica-luterana deve existir (vingar) no Brasil e ampliar a sua estrutura, então é absolutamente necessário que hajam professores e pregadores evangélico-luteranos. Mas de onde conseguir os mesmos? Até agora foram enviados pelo nosso Sínodo de Missouri da América do Norte. Mas lá momentaneamente há grande carência de pregadores. Por ocasião da distribuição dos chamados aos candidatos quase mal e mal a metade dos mesmos (chamados) puderam ser atendidos. Por exemplo, foram requeridos 72 professores, enquanto apenas 27 estavam a disposição.[...] A única saída, o único recurso consiste em que aqui tenhamos professores competentes e afinal que aqui sejam formados.[...] (HARTMEISTER, 1904, p. 184).

O Sínodo acreditava no estabelecimento e no fortalecimento das suas comunidades a partir de uma formação específica e realizada no Brasil, a fim de propagar e constituir uma identidade teológico pedagógica pautada numa sistematização e ordenação na formação de professores e pastores. Inclusive, é ressaltada somente a necessidade de professores, porque se acreditava que o diferencial estava no investimento na educação escolar, não apenas doutrinária, mas na formação geral do professor e pastor.

\section{Conflitos e Disputas na Instalação do Seminário}

Entretanto, as dificuldades não eram só em relação às más condições de estudo e à falta de material didático. O Sínodo, para se estabelecer e para conseguir dominar através do campo religioso o cotidiano de seus fiéis, passou por alguns conflitos e lutas. Seria inevitável que este processo acontecesse, já que nas disputas de diferentes campos e para que se formasse e construísse uma identidade teológico pedagógica era bem possível que aparecessem embates e conflitos que acabaram formatando e criando um processo de organização próprio dos indivíduos inseridos na instituição. Assim, é aceita a análise de Bourdieu (1998), na definição de um campo. Para ele:

Um campo,[...], se define entre outras coisas através da definição de objetos de disputas e dos interesses específicos que são irredutíveis aos objetos de disputas e aos interesses próprios de outros campos.[...] Para que um campo funcione, é preciso que haja objetos de disputas e pessoas prontas para disputar o jogo, dotadas de habitus que impliquem no conhecimento e no reconhecimento das leis imanentes do jogo, dos objetos de disputas, etc. (BOURDIEU, 1998, p. 89)

Nesse sentido, a comunidade no contexto pomerano não possuía um habitus religioso direcionado para a consolidação prevista pela instituição sinodal. Daí resultaram 
muitos conflitos e disputas para que o campo religioso, pautado nos fundamentos doutrinários do Sínodo de Missouri, se consolidasse.

As comunidades pomeranas haviam se organizado para criar igrejas e escolas, mas com outro sentido, de se sentirem parte de uma associação comunitária. O fato de estarem ligadas a uma instituição oficial preocupava-os na medida em que representava o medo de perder a sua autonomia econômica e social. Ao mesmo tempo, o Sínodo investia neste projeto e tentava convencer as comunidades da importância de uma religião organizada e da importância do investimento na formação cristã e geral de pastores e professores.

Um dos primeiros conflitos relatados no artigo "Unser Seminar", do professor Schelp, demonstrava como a questão econômica e a preocupação da comunidade em aceitar o projeto da instituição provocou alguns conflitos e divergências.

[...] A terra pertence a congregação. De fato, aquela pequena construção não poderia passar desapercebida da fúria dos adversários. A testemunha ocular relata: 'Logo que o plano se firmou, a condição de fundar este projeto na comunidade se notava uma desconfiança e inimizade, patrocinada pelos de fora. A pessoa disse: 'Não deixem os norteamericanos construir sobre a terra de vocês. Quando estes senhores se firmarem nunca mais se livram deles'. De fato isto as pessoas acreditaram. (SCHELP, PAUL IN BEER, OTTO 1925, p.84 e 85 Tradução Herbert Weiduschadt)

O que se percebe neste relato é a preocupação com a questão econômica da propriedade. A terra em que seria construído o seminário era da comunidade. A congregação era formada por pessoas que não possuíam a mesma visão do Sínodo de Missouri em relação à organização religiosa. Eles tinham se acostumado a uma organização religiosa mais autônoma, sem maiores vínculos doutrinários a uma instituição. Ainda, havia uma desconfiança em relação ao Sínodo, porque ele não era totalmente originário da Alemanha, a desconfiança aumentava em função da origem do país do Sínodo.

Para eles, o campo religioso era formado a partir de princípios diferentes do Sínodo de Missouri. Eles sentiam a necessidade da religiosidade para cumprir os ritos religiosos e para estarem ligados a uma associação, entretanto, não viam necessidade em possuir pastores com formação específica. Acreditavam que isto poderia ser uma forma de os "norte-americanos" se apossarem de sua propriedade ou regularem seu cotidiano.

Torna-se claro, um "estranhamento" entre estes "dissidentes" e o Sínodo. A própria instituição considera-os como adversários. Não são vistos como luteranos, porque é mencionado no texto que a desconfiança e inimizade vinham de fora. É interessante notar, que "os de fora", enquanto não estavam contra o projeto, pertenciam à organização. Mas no relato, é ressaltado que aqueles que não concordaram com o plano eram vistos como inimigos. Obviamente, esta denotação parte da visão do Sínodo de Missouri, entretanto, não se quer entender os reais motivos da desconfiança de alguns membros, mas assinalar os conflitos e embates acontecidos na constituição do primeiro Seminário, corroborando com a idéia de as disputas e os jogos servirem para consolidar um determinado campo.

Outro relato interessante é do professor Hartmeister, o qual conta com muita propriedade em décadas mais tarde no Mensageiro Luterano os conflitos e as dificuldades do início da construção do seminário. O artigo é escrito pelo referido pastor, em 1951, com o título Semeando o Grão de Mostarda. Provavelmente o pastor Hartmeister encontrava-se nos Estados Unidos, e, assim, escreveu recordando-se como se desenrolaram os conflitos na comunidade.

Ele conta que no dia 22 de julho de 1903 haviam sido comprados 1800 tijolos para a construção do Instituto, mas, antes de arrumar os tijolos um grupo que fazia parte da comunidade reuniu-se na sua casa para impedir a realização do projeto. Eles, timidamente, 
afirmaram que a congregação não queria que fosse construído o seminário, mas Hartmeister não entendia o motivo da mudança de idéia. Todos os argumentos possíveis não adiantaram de nada, eles começaram a se dispersar, até que o pastor Hartmeister não acatou as decisões não considerando esta reclamação válida, porque não havia sido reclamada numa reunião oficial da comunidade. (HARTMEISTER, 1951)

Desde então as dificuldades aumentaram. O pedreiro não queria trabalhar mais na obra. Começaram a intimidar o pastor ameaçando-o com a passagem dos cavalos na estrada durante a noite. Dias depois os mesmos insatisfeitos o procuraram e apresentaram uma lista que continha os nomes dos membros que não estavam de acordo com a construção e disseram que o pastor tinha três meses para ir embora. Mas o pastor Hartmeister relata que agiu com cautela, olhou os nomes da lista e viu que a metade dos membros não havia assinado, e muitos nomes não eram assinaturas, apenas nomes relacionados.

Então, ele propôs uma assembléia da congregação para discutir e resolver o assunto e não ficou parado. Tentou de todas as formas convencerem as pessoas da comunidade antes mesmo da reunião como ele textualmente conta:

Enquanto Emílio Wille (agora pastor daquela mesma congregação em 1947) se punha a caminho em busca de membros da Conferência de São Lourenço afim de os convocar para uma reunião de emergência no domingo seguinte, eu em casa me estafava em descobrir a razão de tôda aquela excitação na comunidade. Fui ter com o colono em cuja residência se realizara a reunião de protesto na noite de segunda-feira. Era o cabeça da oposição. Aqui vim a saber que pessoas de fóra haviam prevenido a nossa gente que não nos permitissem nenhuma construção em seu terreno. Pois, se o fizéssemos, nós poríamos a mão no seu terreno e o tomaríamos para nós (Era a reputação em que ao tempo eram tidos os americanos do norte no Brasil). Uma idéia destas era, naturalmente, ridícula, contudo criara todos aqueles distúrbios. (HARTMEISTER, In: Mensageiro Luterano, janeiro de 1951, Ano XXXVI, no 1, p. 3).

A dificuldade maior era, pois, a aceitação de alguns membros em ter a construção de um Instituto nas terras da Igreja. A preocupação das pessoas recaía sobre a possibilidade da instituição tirar a sua autonomia em relação a decisões da comunidade, e ainda pensavam que poderia representar um risco para aquela comunidade perder a sua propriedade. A maioria dos membros estava acostumada a pertencer a uma associação independente e viam com certa desconfiança a presença de uma instituição confessional, ou seja, uma instituição guiada por um órgão estabelecido nos Estados Unidos.

O pastor Hartmeister continua relatando que não discutiu com este membro, mas argumentou que, se o medo deles era o fato de os norte-americanos ficarem com suas terras, eles mesmos poderia construir com os seus recursos o Instituto. Esta proposta seria levada na Assembléia:

Depois do culto, realizou-se a assembléia da congregação, não na igreja, mas no espaço entre a casa e cozinha. [...] No momento, em que mencionei 'construção', deu-se o pandemônio. Alguns gritaram: 'Não se construirá!', outros: 'Há de se construir!' (Em dialeto germânico: 'Et schall nicht bugt warn!':; 'Et schall doch bugt warn!'). [...] seguindo-se uma pausa, pedi-lhe que me ouvissem. [...] Eu restringiria tanto o custo líquido do material para a construção de uma só peça que poderiam facilmente custeá-la. Orçava em 5 mil réis por membro. Assumindo as despesas a construção proposta se tornaria propriedade dêles, e ninguém lha poderia tirar. (HARTMEISTER, In: Mensageiro Luterano, janeiro de 1951, Ano XXXVI, no 1, p. 3). 
Vê-se que houve necessidade de contornar a situação pelo pastor de uma forma sutil para ganhar a confiança da comunidade. Hartmeister percebeu que não adiantaria enfrentar diretamente as pessoas dissidentes e uma cisão causaria maiores danos para o projeto. A solução foi encontrada no próprio costume comunitário em organizar a igreja entre a comunidade. Cada membro pagaria uma quota pela construção, assim asseguraria o direito de propriedade. Nesta adaptação de ambas as partes, foram possíveis o entendimento.

A construção pôde ser iniciada, porém, não isenta de conflitos. Da mesma forma, o aluno Emílio Wille relata os conflitos que existiram depois da construção. Havia uma desconfiança em relação à instituição e ao projeto. As comunidades não acreditavam totalmente na organização religiosa. Assim, Emílio Wille conta como foi difícil o processo de construção do seminário, do qual ele mesmo participou:

Os tijolos já se achavam no lugar. Fiz o papel de servente de pedreiro. O pedreiro, descrente no sucesso da obra, fazia gracejos a respeito do empreendimento em geral a meu respeito em particular na qualidade de futuro estudante.[...] Quase ultimada a obra do pedreiro, porém correram boatos que caso, fôssem verdadeiros, tudo fracassaria. Já desde o princípio os adversários de nossa igreja instigavam os membros que não haviam concordado com esta construção. Afirmavam que se o Sínodo construísse qualquer obra, conseguiria direitos sobre o patrimônio da comunidade. (EMÍLIO WILLE, In: Mensageiro Luterano, abril de 1949, Ano XXXII, $\mathrm{n}^{\circ} 4$, p. 27).

Apesar de o pastor Hartmeister ter resolvido em parte os problemas da construção, havia muitas desconfianças e contraditoriedades na instalação do projeto. $O$ estudante Emílio Wille já se sentia fazendo parte do Sínodo e estava convicto do seu papel como futuro pastor. Enquanto isso, os que eram contra estavam desacreditados da construção.

Porém não foi possível uma coesão nas comunidades em relação aos interesses religiosos, mas, diante das dificuldades da instalação do Seminário, foi na diferença que se pôde perceber uma construção identitária teológica pedagógica do Sínodo.

Nesse sentido, pode-se reportar conceitos defendidos por Stuart Hall (2000,p.110), acerca da identidade.

Acima de tudo, e de forma diretamente contrária àquela pela qual elas são constantemente invocadas, as identidades são construídas por meio da diferença e não fora dela. Isso implica o reconhecimento radicalmente perturbador de que é apenas por meio da relação com o Outro, da relação com aquilo que não é, com precisamente com aquilo que falta. [...] (HALL, 2000, p. 110).

Nessa perspectiva, o relato do professor Schelp continua mencionando o processo de resistência daqueles que não queriam a instalação do seminário, demarcando a diferença entre o grupo: os que eram adversários e os que apoiavam o projeto do seminário.

E, finalmente quando o pedreiro começou a obra, o pensamento se espalhou e repentinamente à noite os adversários desfaziam o que era construído. Eles (os adversários) sempre faziam suas reuniões em segredo. E de fato a noite (a tardinha) um grupo de opositores se reuniam na estrada, vaiando e praguejando contra o pastor Hartmeister na casa pastoral. Hartmeister, tranqüilo não se importava com isso, continuava lendo, estudando ou quem sabe orando. Bem assim ele fez com que o plano dos adversários não desse certo. E tudo continuava normal. Noutros 
dias os amigos vinham incentivá-lo com o seu projeto, e seu trabalho seguia tranqüilo.[...] (SCHELP, PAUL IN BEER, OTTO 1925, p. 85).

O conflito entre os que eram contrários à construção do Seminário e os defensores do pastor Hartmeister foi, portanto, intenso. Mesmo levando em conta que é uma visão do próprio Sínodo, a repercussão teve importância, já que foi relatada nos mínimos detalhes. Entretanto, o projeto tinha apoio da comunidade, porque alguns incentivavam e apoiavam o pastor. Era necessário também que o pastor se mantivesse calmo diante dos conflitos para que pudesse apaziguar a situação e promover a concretização do projeto e a consolidação do campo religioso. Bourdieu (1998), defende o campo constitutivo de relações de forças que depende dos agentes e das instituições que querem demarcá-lo:

A estrutura do campo é um estado da relação de força entre os agentes ou as instituições engajada na luta ou, se preferirmos, da distribuição do capital específico que, acumulado no curso das lutas anteriores, orienta as estratégias ulteriores. [...] Outra propriedade, já menos visível de um campo: todas as pessoas que estão engajadas num campo têm um certo número de interesse fundamentais em comum, a saber, tudo aquilo que está ligado à própria existência do campo: daí a cumplicidade objetiva subjacente a todos os antagonismos.[...]( BOURDIEU, 1998, p. 89)

O campo religioso desta comunidade foi sendo construído entre diferenças e conflitos. Era evidente ser necessário de criar um campo religioso que influenciasse e até mesmo se sobrepusesse aos demais campos: como o da família, do trabalho e até do lazer. ${ }^{11}$ A idéia de obter uma identidade teológico pedagógica, sistematizá-la e organizá-la sob a orientação do Sínodo de Missouri foi observada nas práticas da instituição. Esta identidade se constituiu, ao mesmo tempo, nas diferenças e também nos interesses em comum que apareceram entre os grupos.

Nesse contexto, a formação da identidade teológica pedagógica deu-se a partir da constituição de um campo religioso, e, portanto, fortaleceu uma identidade religiosa, ultrapassando a identidade de classe, étnica ou econômica, sem no entanto, estarem sobrepostas uma a outra, mesmo estando relacionadas. Podemos observar esta afirmação nos conceitos defendidos por Smith (1997):

[...] Tanto identidades religiosas como étnicas se empenharam em incluir mais do que uma classe dentro das comunidades formadas sobre as suas bases. As comunidades religiosas, quando aspiram a tornar-se Igrejas, atraíram todos os sectores de uma determinada população ou mesmo as que existiam para além das fronteiras étnicas.[...] As formas muito diversas de 'religião de classe' referidas por Weber sugerem as estreitas ligações entre identidades religiosas e de classe e o freqüente 'deslize' de uma sobre a outra'.

Contudo, a 'identidade religiosa' baseia-se em critérios bastante diferentes de acção e de necessidades humanas. Ao passo, que as identidades de classe emergem da esfera da produção e troca, as identidades religiosas derivam das esferas da comunicação e socialização. Baseiam-se em alinhamentos da cultura e dos seus elementos- valores, símbolos, mitos e tradições, muitas vezes sistematicamente em costumes e rituais. (SMITH, 1997, p. 19).

Ao diferenciar identidade religiosa formada a partir do campo religioso, não se quer defender que ela se dá de forma isolada ou numa posição binária (conceito utilizado por Stuart Hall), ou seja, identidade de classe versus identidade religiosa. Mas ao concordar 
com estes conceitos levanta-se a possibilidade da identidade religiosa estar imbuída de processos de sociabilidade e ser fortalecida através de símbolos e crenças, possuindo uma especificidade própria, embora na sua constituição preserve elementos de outras identidades, como a questão da identidade étnica e de identidade de classe.

No relato dos conflitos existentes na fundação do seminário, fica evidente que o grupo era composto por uma mesma etnia: a pomerana. Neste aspecto, eles se identificavam, a não ser em relação ao pastor Hartmeister, que pertencia a outra etnia, bem como era oriundo de outro país.

Mas a identificação ocorre através da diferença: os que apoiaram o projeto se viram cada vez mais identificados com o Sínodo de Missouri, na medida em que se diferenciaram dos opositores. A demarcação da diferença é processual, ela aconteceu através dos conflitos. Para aqueles que apoiavam o projeto, a constituição de uma identidade teológica pedagógica era fortalecida e consolidada no grupo, como também para aqueles que se opunham. Os opositores, definiam também uma identidade religiosa diferente e contrária ao Sínodo, procuravam impedir a concretização deste projeto e, assim, definir uma identidade religiosa contrária.

Nos conflitos, o interesse econômico e social aparece de forma clara, a questão das terras e da propriedade era mais relevante para os contrários ao Sínodo, do que a aceitação da doutrina e da forma de organização da instituição sinodal. Se a identidade religiosa, como foi exposto anteriormente, é construída a partir de símbolos, rituais, em costumes e tradições, a identidade teológica pedagógica que o Sínodo buscava imprimir, não deixaria de abalar a base religiosa existente na comunidade.

Entretanto, foi inferido que o Sínodo de Missouri tentou demarcar uma identidade teológica pedagógica diferenciada em relação ao que acontecia no contexto pomerano. As comunidades foram orientadas pelo campo religioso em praticamente todas as esferas do cotidiano. Para cumprir estes objetivos a necessidade de fundar estabelecimentos escolares e também criar um seminário na zona rural foi essencial para a consolidação deste projeto.

\section{Término do Seminário de Bom Jesus e o início em Porto Alegre e o impacto nas escolas paroquiais}

O seminário em Bom Jesus durou pouco. O seu funcionamento na região de São Lourenço permaneceu por dois anos e tentou preparar alguns jovens mesmo com as precárias condições apresentadas. Assim como na primeira Assembléia Sinodal em Rincão de São Pedro em 1904, o entusiasmo pelo projeto do Seminário em Bom Jesus era grande. Em 1905 na segunda Assembléia Sinodal em Jaguari o Sínodo revela que o Instituto na região de São Lourenço tinha sido muito desgastante, devido à distância da capital de Porto Alegre. Na região central haveria mais possibilidade de crescimento e aceitação de professores dos Estados Unidos para trabalhar. (DER LUTHERANER, 1904 e 1905) com o Instituto.

Mas, somente em 1906 na Conferência em Toropi que foi decidido o que se faria

Sobre o Instituto a reunião trouxe novas conotações. Por enquanto, o plano original da transferência para Porto Alegre não se desenvolveu como se devia. Há falta de pessoas que tenham coragem para o ensino. Sobre os alunos que prontamente num ano foram instruídos e que tiveram a chance de receber a instrução para não perderem foram colocados em escolas pequenas, e mais tarde poderão praticar e aplicar em campo. Assim que o ensino verdadeiro se fixar em Porto Alegre então o Instituto será reaberto. (DER LUTHERANER, 10/04/1906, Ano 62, nº 8, p. 126)

As dificuldades eram as mesmas. Falta de pessoal capacitado para a instrução. Mas os alunos foram conduzidos nas escolas mesmo com um ano de estudo. O aproveitamento 
maior foi no campo pedagógico. Emílio Wille relata o final do Instituto e o destino dos primeiros estudantes.

\begin{abstract}
Infelizmente, em maio de 1905, o pastor Hartmeister viu-se forçado a regressar para os Estados Unidos, devido o precário estado de saúde de sua espôsa. Como o sucessor do pastor Hartmeister não pudesse atender as aulas do Instituto, os estudantes tiveram que voltar para as suas casas, mas por pouco tempo. (EMÍLIO WILLE, In: Mensageiro Luterano, abril de 1949, Ano XXXII, nº4, p. 27).
\end{abstract}

É bem provável que os estudantes tenham ficado decepcionados com o término do Instituto. Decerto ficaram tristes após tanto esforço durante aquele ano. Mas, logo em seguida, eles puderam aproveitar os seus conhecimentos, atuando nas escolas religiosas do Sínodo de Missouri.

[...] O estudante Adolfo Flor entrou numa escola em Santa Maria como auxiliar. O estudante Evaldo Hirschmann atendeu sucessivamente as escolas de Santa Helena e Santa Eulália. O estudante Henrique Drews lecionou na escola da comunidade de Costa do Arrôio Grande. E o signatário destas linhas tomou conta da escola de Santa Coleta. (EMÍLIO WILLE, In: Mensageiro Luterano, abril de 1949, Ano XXXII, nº, p. $27)^{12}$.

Apesar de ter funcionado por pouco tempo o Seminário preparou estes jovens para atuar especialmente nas escolas pomeranas da região, enquanto aguardavam a possibilidade da conclusão dos estudos. Apenas o estudante Adolfo Flor não atuou na região de Pelotas e São Lourenço do Sul inicialmente, mas depois retornou em 1910 para atender Bom Jesus. Os outros estudantes permaneceram por muito tempo na região inicial do Sínodo. Mas, depois de reaberto o Seminário em Porto Alegre, a maioria dos estudantes teve continuidade de sua formação lá.

Em 1907 o Seminário foi reaberto em Porto Alegre. Seguiram para lá os estudantes Francisco Hoffmann e Evaldo Hirschmann e desistiu dos seus estudos Henrique Drews, enquanto Adolfo Flor e eu concluímos os nossos estudos no seminário de Springfield de Illinois, nos Estados Unidos. (EMÍLIO WILLE, In: Mensageiro Luterano, abril de 1949, Ano XXXII, no 4 , p. 27).

Desses quatro estudantes ${ }^{13}$ que continuaram a sua formação teológica e pedagógica, ou seja, foram formados pastores e professores, apenas um seguiu somente a formação pedagógica, este foi o estudante Francisco Hoffmann.

Mas o que se destaca é o trabalho realizado pela maioria destes estudantes na realidade pomerana, assumindo as escolas na função de professor.

Entretanto, a conclusão dos estudos daqueles que continuaram estudando deu-se em instituições do Sínodo de Missouri e eles continuaram como pastores e professores em escolas e igrejas. $\mathrm{O}$ relato do Der Lutheraner confirma o fim do Instituto "O Instituto foi fechado, pois estava no 'meio do mato' e transferido para Porto Alegre o que se deu em 1905. Dois que já haviam se adiantado nos estudos de pastor e professor foram terminar os estudos em Springfield.” (DER LUTHERANER, 21/05/1907, Ano 63, nº17, p. 167)

Fica demonstrado assim que o Sínodo havia crescido em outras regiões do Estado, por isso, precisava remodelar a instituição de ensino. O Seminário Concórdia em Porto Alegre foi reaberto em 1907 com uma maior estrutura física e pedagógica e formou um grande número de professores e pastores. 

instituição.

Em 1909, as notícias sobre o Seminário reaparecem, justificando a eficiência da

O instituto em Porto Alegre com o diretor Weghaupt decidiu dar um relatório. Em três anos, três professores se formaram, era o segundo ano de aula e pudemos abrir com dez alunos, deste cinco foram novos que entraram. E no decorrer de dois anos foram ser professores e três permaneceram como alunos. O nome foi resolvido: Seminário Evangélico Luterano Concórdia.[...] Também a questão curricular foi ricamente aprofundada. Uma comissão se dedica a fazer um plano para as escolas rurais e as escolas da cidade.[...] (DER LUTHERANER, 04/05/1909, Ano $65, \mathrm{n}^{\circ} 9$, p. 133).

A ampliação do Seminário e o fortalecimento da instituição teve como finalidade suprir o trabalho de pastores e em especial, as escolas. A formação de alguns alunos era mais rápida devido à necessidade de mais trabalhadores nas escolas e nas igrejas. Fica evidente que a preocupação do Sínodo era orientar, através de um plano curricular adaptado para as escolas rurais e urbanas.

Mas as dificuldades em formar pessoal capacitado permaneceram por um bom tempo na preocupação do Sínodo. Em 1911 numa avaliação do Seminário em Porto Alegre continuou o alerta para o pouco tempo de preparação dos alunos.

É uma situação extremamente embaraçosa que um aluno, após somente um ou dois anos de estudo no seminário, tenham de sair para assumir postos em escolas do interior. Isso deve ser trabalhado de forma a se tornar algo cada vez menos necessário e, se for absolutamente necessário, que os estudantes dêem assistência, eles deveriam ser chamados somente após quatro anos de ensino. [...] (KIRCHENBLATT, 15//01/1911, Ano 8, n $^{\circ} 2$, p. 11).

É possível notar que a falta de professores nas escolas era grande e o projeto do Sínodo contemplava de forma particular a escolarização religiosa e com orientação de pessoal capacitado e competente a fim de oferecer uma diferenciação. Se os professores não estivessem preparados, a educação correria o risco de fracassar ou não demonstrar a competência do Sínodo. Mas, mesmo assim, era preciso adaptar a situação à realidade encontrada. Muitas escolas precisavam de professores e não era possível esperar o tempo de formação. Entretanto, o Sínodo colocou essa preocupação na revista oficial para os membros e as comunidades terem ciência do que estava acontecendo.

O Seminário Concórdia, localizado em Porto Alegre, permaneceu por muito tempo funcionando como uma instituição de formação de professores e pastores.

Apesar de a pesquisa privilegiar o Seminário em Bom Jesus, acreditamos ser importante referendar à continuidade do projeto em Porto Alegre, porque a continuidade da formação dos primeiros pastores e professores que atuaram nas escolas pomeranas deu-se naquela instituição.

O projeto do Seminário em Bom Jesus foi reverenciado em anos posteriores pelos periódicos do Sínodo apontando como um marco pioneiro do Sínodo em começar naquelas condições um curso preparatório de professores e pastores.

Nos quatro periódicos analisados: Der Lutheraner, Kirchenblatt, Mensageiro Luterano e Jovem Luterano em reportagens posteriores ao fechamento do Seminário em Bom Jesus os relatos narram homenagens deste empreendimento como sendo essencial na projeção do Sínodo no Brasil. A partir dele foi possível acreditar que a missão no Sínodo seria possível. Mesmo tendo funcionado por pouco tempo, nos periódicos do Sínodo este estabelecimento é retratado como um projeto de coragem e humildade, com pessoas da 
comunidade, professores e alunos que tiveram desprendimento e disciplina para conseguir levar o projeto adiante e formar alguns jovens para trabalhar nas primeiras escolas do Sínodo. ${ }^{14}$

Ainda pode-se encontrar depoentes ${ }^{15}$ que foram alunas e alunos dos primeiros estudantes, já que, dentre eles, muitos foram professores nas escolas pomeranas.

\section{Considerações Finais}

Para a legitimação como "verdadeira igreja luterana" não bastava o Sínodo se enxergar como tal. Precisava convencer as comunidades. Uma das formas encontradas era a preocupação que o Sínodo tinha em relação à educação. Uma educação doutrinária foi expandida através da organização escolar. Apesar dessas comunidades já possuírem uma organização escolar anterior à instalação do Sínodo, a instituição oferece uma educação dita por eles como diferente.

A educação necessitava de pessoal qualificado. Não poderia ser colocado nas escolas ligadas ao Sínodo de Missouri professores desqualificados, nem tampouco nas igrejas, pastores sem formação teológica.

Por isso, num primeiro momento o Sínodo, trouxe seus pastores e professores dos Estados Unidos, todos com formação específica, formados nos seminários norteamericanos, mas ressentiu-se da falta de pessoal para trabalhar nas comunidades inseridas no Sínodo. Nesse ponto, o Sínodo não podia atender sem pessoal qualificado, pois precisava ser diferente das outras instituições, nem tampouco, podia aceitar qualquer pastor ou professor. Assim, o Sínodo começou um projeto que visava à formação de pastores e professores. Em situação precária, a fundação do primeiro seminário no interior de São Lourenço do Sul foi relevante porque foi possível visualizar as tentativas do Sínodo em estabelecer-se no Brasil. O projeto do Seminário foi um fator determinante da formação da identidade do Sínodo de Missouri, porque promoveu uma escolarização de estudantes que puderam atuar nas comunidades pomeranas.

A sua fundação foi escolhida em uma comunidade pomerana. A maior parte dos seus alunos eram pomeranos. Esse projeto se justificava na falta de recursos humanos para atuar nas igrejas e escolas. Segundo os relatos do Sínodo o principal motivo era evitar gastos, bancando viagens aos missionários norte-americanos, os quais, muitas vezes, não se adaptavam à realidade brasileira. Esse era um motivo contundente.

Mas o que aparece claramente é a formação de jovens brasileiros como professores e pastores, orientados pela doutrina considerada pura pelo Sínodo. Assim, ao mesmo tempo em que se evitavam gastos, era possível formar pessoas que iriam atuar no meio em que viviam.

Nesse sentido, constata-se que a necessidade de se diferenciar e demarcar uma identidade foi valorizada pelo Sínodo. A partir da formação teológica e pedagógica de jovens estudantes foi possível moldar as condutas e interiorizar habitus condizentes com os seus princípios e fortalecer o campo religioso.

\section{Referências}

BOURDIEU, Pierre. Pierre Bourdieu entrevistado por Maria Andréa Loyola. Rio de Janeiro, UERJ, 2002.

BOURDIEU, Pierre. Razões Práticas sobre a teoria da ação. Campinas, Papirus, 1996a. BOURDIEU, Pierre. A Economia das trocas lingüísticas: o que falar e o que dizer. São Paulo, USP, 1996b.

BOURDIEU, Pierre. O Poder Simbólico. Lisboa, Difel, Bertrand Brasil, 1989. 
DREHER, Martin Norberto. Igreja e Germanidade: Estudo Crítico da História da Igreja Evangélica de Confissão Luterana no Brasil. Porto Alegre, EST, 1984.

GERTZ, René. O Perigo Alemão. 2ª ed. Porto Alegre, Universidade/ UFRGS; 1998

HALL, Stuart. Quem precisa de identidade? IN: SILVA, Tomás T. da (org.). Identidade e diferença: a perspectiva dos estudos culturais. Petrópolis: Vozes, 2000, p. 103-133.

HARTMEISTER, Jonh. Ein Institut zur Ausbildung von Lehrern und Predigern.

Evangelisch Luterisches Kirchenblatt. Porto Alegre, 37-40, 1904.

HARTMEISTER, Jonh. Ein Tag bei unsern Zoglingen. Evangelisch Luterisches Kirchenblatt. Porto Alegre, 180- 188, 1904.

REHFELDT, Mario L. Um grão de mostarda: A História da Igreja Evangélica Luterana do Brasil. Porto Alegre, Concórdia, 2003. v.1.

REHFELDT, L. C. Unsere Schulen IN: Beer, Otto. 25 Jaher unter dem Sudlichen Kreutz (1900-1925). Porto Alegre, Concórdia, 1925.

SCHELP, PAUL IN BEER, Otto. 25 Jaher unter dem Sudlichen Kreutz (1900-1925). Porto Alegre, Concórdia, 1925.

SMITH, Anthony D. A identidade nacional. Lisboa: Gradiva, 1997. [Cap. 1: Identidades nacionais e outras, $\mathrm{p}$ 13-33]

TEICHMANN, Eliseu. Imigração e Igreja: As comunidade- Livres no Contexto da Estruturação do Luteranismo no Rio Grande do Sul. São Leopoldo, Instituto Ecumênico de Pós Graduação, Tese de Mestrado, 1996.

WARTH, Carlos H. Crônicas da Igreja: Fatos históricos da Igreja Evangélica Luterana do Brasil: 1990- 1974). Porto Alegre, Concórdia S. A ., 1979.

WEBER, Max. A ética Protestante e o Espírito do Capitalismo. $7^{\mathrm{a}}$ ed. Livraria Pioneira Editora, 1992.

WEIDUSCHADT, Patrícia. O Sínodo de Missouri e a educação pomerana em Pelotas e São Lourenço do Sul nas primeiras décadas do século XX: identidade e cultura escolar. Pelotas, Programa de Pós-Graduação em Educação, Ufpel, 2007. Dissertação de mestrado.

WEIDUSCHADT, Patrícia. O Lazer e a construção da identidade numa comunidade rural de descendentes germânicos em Pelotas. Pelotas, ICH/UFPEL, setembro de 2004, monografia de especialização.

Periódicos e revistas pesquisadas.

Der Lutheraner, St Louis, Concordia Publishing House, 1899-1915. Revista Oficial da The Lutheran Church Missouri Synod (EUA)

Evangelisch- Lutherisches Kirchenblatt Sued-Amerika, Porto Alegre, 1903-1904; 19081913- Revista Oficial da Igreja Evangélica Luterana do Brasil.

Jornal do Comércio, O2/03/1875, nº 48, p. 1. Pelotas.

Artigos do Mensageiro Luterano:

WILLE, Emílio. Nosso Primeiro Seminário em Bom Jesus, São Lourenço do Sul, R. G. S. Mensageiro Luterano. Rio de Janeiro, abril de 1949, Ano XXXII, nº 4, p. 26-27.

HARTMEISTER, Jonh. Semeando o Grão de Mostarda. Mensageiro Luterano. Rio de Janeiro, janeiro de 1951, Ano XXXVI, nº 1, p.2-4. 


\section{Artigo do Jovem Luterano:}

REHFELDT, L. C. O Grão de Mostarda que se fêz Árvore. Jovem Luterano. Porto Alegre, agosto de 1949, Ano X, no 8, p. 118-124.

${ }_{1}^{1}$ Professora efetiva da Universidade Federal de Pelotas. Doutora em Educação.
${ }^{2}$ Professor efetivo da Universidade Federal de Pelotas. Doutor em Educação.
${ }^{3}$ O Sínodo de Missouri foi uma instituição religiosa fundada nos Estados Unidos por imigrantes alemães. Atualmente é chamada de Igreja Evangélica Luterana do Brasil (IELB). Esta instituição estabeleceu-se nas regiões de Pelotas e São Lourenço do Sul em 1900 e fez parte do meu estudo de mestrado na relação com as escolas pomeranas. Para saber mais ver em Reefehldt ( 2003), Steyer (1999); Warth (1979).

4 O Sínodo Riograndense é uma instituição religiosa de cunho luterano. Esta instituição já havia se estabelecido no Brasil anos antes do Sínodo de Missouri, possuindo algumas comunidades no norte do Estado com características associativas marcantes entre igrejas e escolas. Para saber mais, ver em René Gertz, O perigo alemão (1998); Walther Steyer (1999) Os imigrantes alemães no Rio Grande do Sul: a fundação da IELB e o confronto com o Sínodo Riograndense 1900-19004 e Martin Dreher, Igreja e Germanidade (1984).

${ }^{5} \mathrm{O}$ pastor Broders foi o primeiro pastor a sondar a realidade brasileira para a instalação do Sínodo. Ele foi enviado na condição de preposto da instituição para tentar viabilizar a fundação do Sínodo no Brasil.

${ }^{6}$ As comunidades independentes luteranas é um processo recorrente entre os imigrantes pomeranos. Eles buscaram organizar as suas escolas e igrejas sem nenhum vínculo hierárquico e sinodal. Para saber do movimento do independentismo religioso, ver em Eliseu Teichmann (1996) dissertação de mestrado.

${ }^{7}$ As primeiras comunidades do Sínodo de Missouri foram fundadas no interior de Pelotas e São Lourenço do Sul, com o predomínio da etnia pomerana. Foram elas: São Pedro e Santa Coleta no interior de Pelotas, e Bom Jesus no interior de São Lourenço do Sul.

${ }^{8}$ Os primeiros pastores enviados dos Estados Unidos que atuaram nesta região foram: o pastor Mahler na colônia São Pedro e, posteriormente, os pastores: A. Vogel, H. Stiemke e J. Hartmeister. (Steyer, 1999).

${ }^{9}$ Para aprofundar esta questão ver em Steyer (1999); Warth (1974).

${ }^{10}$ Segundo dados e relatos do periódico Der Lutheraner sobre os seminários norte- americanos. Versavam sobre a estrutura física, inclusive com imagens, como o corpo docente e a estrutura curricular.

${ }^{11}$ Em relação ao campo do lazer, reforço os estudos anteriores abordando esta temática como monografia de especialização. WEIDFUSCHADT, Patrícia. Lazer e a construção identitária numa comunidade rural de descendentes de imigrantes alemães em Pelotas. Pelotas, ICH-UFPEL, 2004. Neste estudo era possível perceber o campo religioso influenciando o campo do lazer.

${ }^{12}$ A fim de esclarecer as localidades citadas percebemos que apenas Adolfo Flor atuou em Santa Maria região central do Estado do RS, os demais Evaldo Hirschmann, Henrique Drews e Emílio Wille atuaram em comunidades localizadas na região do interior de Pelotas.

${ }^{13}$ De acordo com dados do Mensageiro Luterano e das Crônicas da Igreja sobre os estudantes formados no Seminário, percebemos que depois destes terem atuado nas escolas continuaram seus estudos. Formaram-se nos seguintes anos: em 1910 formou-se Adolfo Flor nos Estados Unidos, permanecendo em Bom Jesus São Lourenço do Sul entre 1910-1913; Emílio Wille formou-se com Adolfo Flor, atuando nas escolas da região de Pelotas e São Lourenço do Sul de 1911- 1923, em 1933 atuou como pastor na mesma região; Evaldo Hirschmann formou-se no Seminário Concórdia em 1915, atuando em Santa Coleta de 1921-1937 como pastor e professor; Francisco Hoffmann formou-se apenas como professor e foi o único que não atuou na região de Pelotas e São Lourenço do Sul. (WARTH, 1979; MENSAGEIRO LUETRANO, 1949)

${ }^{14}$ Muitas reportagens posteriores de homenagem ao Seminário encontram-se publicadas nos periódicos analisados. No KIRCHENBLATT há relatos nos números 01/12/1915, Ano 12, no 23 p. 179 e 01/02/1929, Ano 24, no 3, p. 18-19, com o título: "Discurso festivo feito durante o jubileu do seminário". Também no DER LUTHERANER, 16/03/1915, Ano 71, nº 6, p. 104. Ainda, no MENSAGEIRO LUTERANO, Nosso Primeiro Seminário em Bom Jesus relatado por Emílio Wille, abril de 1949, Ano XXXII, no 4, p. 26-27; Semeando o Grão de Mostarda, relatado por Hartmeister janeiro de 1951, Ano XXXXVI, no 1, p. 2-4. No JOVEM LUTERANO, a O Grão de Mostarda que se fêz árvore, agosto de 1949, Ano X, nº 8, p 118- 120.

${ }^{15} \mathrm{O}$ trabalho da dissertação contemplou entrevistas com alunos e alunas destes primeiros professores.

Recebido em abril/2012

Aprovado em julho/2012 